\title{
Variability of Speech Sound Production according to Phonetic Complexity in Children with and without Speech Sound Disorders
}

\author{
Eun-Ji Han ${ }^{\mathrm{a}}$, Ji-Wan $\mathrm{Ha}^{\mathrm{b}}$ \\ aDepartment of Rehabilitation Science, Graduate School, Daegu University, Gyeongsan, Korea \\ ${ }^{b}$ Department of Speech Pathology, Daegu University, Gyeongsan, Korea
}

\author{
Correspondence: Ji-Wan $\mathrm{Ha}, \mathrm{PhD}$ \\ Department of Speech Pathology, Daegu \\ University, 201 Daegudae-ro, Jillyang-eup, \\ Gyeongsan 38453, Korea \\ Tel: $+82-53-850-4327$ \\ Fax: $+82-53-850-4329$ \\ E-mail: jw-ha@daegu.ac.kr
}

Received: October 5, 2017

Revised: November 16, 2017

Accepted: November 20, 2017

This work was supported by the National Research Foundation of Korea Grant funded by the Korean Government (NRF-2017R1C1B1010913).

This work was an excerpt from the master's thesis of the first author (2017).

\begin{abstract}
Objectives: This study investigated the proportion of articulatory errors, variation of articulatory production, variation of articulatory errors, and deviation of reaction time according to phonetic complexity in children with and without speech sound disorder (SSD). Methods: The study subjects were 20 SSD children and 60 typically developing (TD) children from 3 to 6 years of age. Subjects produced words with high and low phonetic complexity four times. Subjects' responses were recorded using DmDX display software for measuring articulatory variability. Results: In the TD group, proportion of articulatory errors, variation of articulatory production, variation of articulatory errors, and deviation of reaction time were lower as age increased; and the four types of measures of variability were higher at the 'high'level than in the 'low'level of phonetic complexity. The SSD group showed a higher proportion of articulatory errors and higher variation of articulatory errors than the chronological age (CA)-matched children group. In the SSD group, all types of measures of variability were higher at the 'high' level than in the 'low' level of phonetic complexity as in the CA group. Conclusion: Articulatory variability is not purely a characteristic of the inconsistent phonological disorder' group, but a more general symptom of both TD and SSD children. Thus, different kinds of variables among these groups have to be more fully analyzed.
\end{abstract}

Keywords: Speech sound disorder, Articulatory variability, Phonetic complexity 말소리장애(speech sound disorder, SSD)는 말장애 가운데 발음 에 문제가 있는 경우로, 지속적인 말소리 산출 문제로 인해 구어 의 사소통의 효율성이 떨어지는 장애를 말한다(Kim \& Shin, 2015). 말 소리장애는 '원인이 분명한 말소리장애(SSD with known origin)' 와 ‘원인을 모르는 말소리장애(SSD with unknown origin)'로 분류 할 수 있는데, Diagnosis and Statistical Manual-5 (DSM-5)에서는 ‘말소리장애’라는 진단명을 ‘원인 모르는 말소리장애’에 국한하여 사용한다. 원인 모르는 말소리장애의 '근본적 원인(origin)'을 밝히 고자 하는 노력은 여러 연구자들에 의해 꾸준히 이루어져 오고 있 다. 그러나 이것은 매우 요원한 작업인 만큼, 그 대안책으로 이질적 인 말소리장애를 하위집단들로 분류할 것을 제안한 연구들을 찾 아볼 수 있다. Dodd, Holm, Crosbie와 McCormack (2005)의 연구 가 그 중 하나로, 이들은 원인 모르는 말소리장애를 증상에 따라 네
집단으로 분류할 것을 제안하였다. 증상적 분류는 본질적으로 문 제의 원인에 대해 설명해 주지는 못하지만, 표면적으로 관찰할 수 있는 오류패턴을 통해 말소리장애를 하위집단들로 분류하고 각 하 위집단의 공통적 요인들을 찾는 것이 현재로서는 최선이라고 설명 하였다.

상이한 말소리 오류패턴에 근거하여 Dodd 등(2005)이 분류한 네 가지 하위집단은 조음장애, 음운지체, 일관적인 음운장애, 비일 관적인 음운장애이다. 조음장애, 음운지체, 일관적인 음운장애는 기존의 표준화된 조음·음운 평가방법 또는 자발화 분석 등을 이용 하여 오류패턴을 분석함으로써 분류가 가능하다. 그러나 비일관적 인 음운장애의 경우 비발달적 오류패턴뿐 아니라 비일관적 말소리 산출오류를 그 특징으로 하기 때문에, 하나의 말소리에 대해 단 한 차례의 산출기회만을 제공하거나 여러 차례의 산출기회가 있더라 
도 문맥적 다양성을 통제하지 않은 기존의 평가방법으로는 분류가 불가능하다. 비일관적 말소리 산출오류는 동일한 목표단어를 여러 차례 산출했을 때 산출한 발음의 형태가 얼마나 다양하게 나타나 는지를 통해 알 수 있다. 때문에 기존 평가방법과는 다르게 동일한 말소리 형태를 문맥 변화 없이 똑같은 단어에서 여러 차례 산출하 게 하는 방법이 요구된다.

비일관적 음운장애를 변별진단하기 위해서는 말소리 산출체계 에서 적어도 $40 \%$ 의 변이성이 관찰되어야 한다(Dodd et al., 2005). 이와 같은 변이성을 초래하는 기저의 관련요인으로 Dodd 등(2005) 은 산출처리과정상의 두 가지 측면, 음운계획장애와 음성프로그래 밍장애를 언급하였다. 음운계획장애는 음운산출완충기(phonological output buffer)상에서 음소를 선택하고 배열하는 것의 어려 움으로 설명된다. 음성프로그래밍장애는 추상적 음운계획으로부 터 정확한 조음 지시사항을 프로그래밍하는 과정, 그리고 그 운동 프로그램으로부터 조음메커니즘의 근육운동들을 동시에 협응적 으로 조절하는 과정에 이르기까지 결함에 대한 범위가 상당히 넓 다. 음운계획은 추상적 음운산출처리에서 최종적으로 음운을 부 호화하는 과정에 해당한다. 반면 음성프로그래밍은 앞으로 일어 날 조음운동에 대한 '계획'이라는 정신적 처리과정부터 현재 진행 되고 있는 조음운동에 대한 '조절'이라는 말초적 단계까지의 과정 을 모두 포함한다고 볼 수 있다. 크게 분류하면 음운계획의 경우는 '음운처리의 마지막 단계'에 해당하고, 음성프로그래밍의 경우는 '조음처리의 첫 단계'에 해당하며 말실행증을 초래하는 과정과 그 맥락이 닿아있다. 이처럼 변이성이 음운의 끝과 조음의 시작이라 는 본질적으로 차원이 매우 다르면서도 서로 맞닿아있는 단계의 문제들이라는 점은 비일관적 음운장애의 진단을 더욱 어렵게 하 는 요인인 듯하다.

진단을 더욱 어렵게 만드는 또 다른 요인은, 변이성이 앞에서 설 명하였던 음운계획장애 또는 음성프로그래밍장애와 같은 병리적 문제와 관련이 있는 한편, 일반 아동의 말소리 발달과정에서도 흔히 관찰되는 정상적 발달 특성이기도 하기 때문이다(Macrea, 2013). 국내에서도 이와 관련한 연구를 찾아볼 수 있는데, Hwang과 $\mathrm{Ha}$ (2012)는 일반 아동의 말소리발달과정 중 3세 이전의 어린 연령의 아동은 조음오류율도 높지만 이와 더불어 조음변이성과 조음오류 의 변이성도 많이 보인다고 보고하였다. 조음오류의 경우에도 일반 아동의 정상 발달과정에서 나타나는 흔한 특성이기도 하지만 말소 리장애라는 병리적인 말장애를 진단하는 결정적 근거와 기준이 된 다는 점을 상기하면, 어쩌면 이는 당연한 것으로 여겨진다. 말소리 장애를 진단하기 위해 일반 아동들의 말소리 오류 및 오류패턴의 발달과정을 파악하고 그것에 근거하여 일반 아동과 말소리장애 아
동 간 집단적 차이를 확인하는 것이 중요한 것처럼, 변이성에 대해 서도 정상적 발달과정과 병리적 발달과정을 구분하기 위해 이와 동 일한 절차가 필요할 것이다.

따라서 비일관적 음운장애의 진단을 위해서는 말소리 산출의 변 이성에 대해 학령전기 일반 아동을 대상으로 정상적인 발달과정을 알아보고, 동일 연령대의 말소리장애 아동과 일반 아동의 변이성 에 어떤 차이가 있는지를 알아보는 것이 중요하다. 이와 관련된 선 행연구들을 살펴본 결과, 3-3세 5개월 일반 아동이 목표단어의 $13 \%$ 를 가변적으로 산출하였다는 연구(Holm, Crosbie, \& Dodd, 2007), 2-3세 일반 아동이 목표단어의 53.7\%를 가변적으로 산출하 였다는 연구(McLeod \& Hewett, 2008), 말소리장애 집단에서 조음 변이성이 있는 대상자가 $38.6 \%$ 에 달하였다는 연구(Kim, Kim, Ha, $\& \mathrm{Ha}, 2015)$, 말소리장애 아동이 목표단어의 $15 \%$ 는 최소 가변적으 로, 79\%는 최대 가변적으로 산출한다는 연구(Macrea, Tyler, \& Lewis, 2014) 등 일반 아동과 말소리장애 아동 두 집단 모두에서 변 이성에 대한 측정치는 매우 상이하였다. 이와 같은 결과가 초래된 이유 중 하나로 변이성을 측정하는 방법의 다양성을 생각해볼 수 있다. 말소리 변이성을 평가하기 위해 Ingram (2002)은 단어단위 변이성 비율(proportion of whole-word variation, PWV)을, Betz와 Stoel-Gammon (2005)은 최고 빈도 오류에 대한 변이성 비율을, Haley, Jacks와 Cunningham (2013)은 전체 오류에서 서로 다르게 오조음한 비율과 전체 음소에서 서로 다르게 산출한 비율을 측정 하는 등 연구마다 각각 다른 지표로 분석하였다.

연구들마다 서로 다른 결과가 나타난 또 다른 이유로 조음산출 시 동반되는 조음복잡성에 대해서도 생각해보아야 할 것이다. 조 음복잡성은 언어단위 내에서 음성학적으로 복잡한 정도를 의미한 다. 변이성에 대한 Holm 등(2007), McLeod와 Hewett (2008), Sosa 와 Stoel-Gammon (2012)의 연구를 비교해보면, 각 연구에서 분석 하였던 단어들의 조음복잡성은 매우 단순한 것에서 복잡한 것까 지 그 정도가 상당히 다양하였다. 일찍 습득되는 말소리보다 늦게 습득되는 말소리로 이루어진 단어가 덜 정확할 뿐 아니라 더욱 비 일관적이라는 선행연구(Macrea, 2013), 그리고 조음복잡성이 낮은 단어가 발달과정상 일반적으로 더 먼저 습득된다는 말소리발달에 대한 보편적 지식을 종합해볼 때, 조음복잡성이 말소리 산출 시 변 이성에 영향을 미치는 요인임을 부정할 수 없다.

따라서 연구마다 상이한 지표와 분석방법을 사용함으로써 초래 될 수 있는 결과해석의 제한점을 보완하고자, 본 연구에서는 선행 연구에서 다루었던 여러 변이성 지표들, 즉 조음오류율, 조음산출 의 변이성, 조음오류의 변이성, 반응시간의 변이성을 모두 측정지 표로 삼았다. 또한 조음복잡성이 높은 단어와 낮은 단어로 목표단 
어를 분류하여, 말소리 산출의 변이성에 조음복잡성이 미치는 영 향에 대해서도 알아보고자 목표단어를 조음복잡성 '저'와 '고' 항 목으로 나누고, 목표단어에 해당하는 그림에 대하여 그것의 이름 을 여러차례 산출하도록 하였다.

이상과 같은 본 연구의 연구질문을 정리해보면 다음과 같다. 첫 째, 학령전기 일반 아동에서 연령 집단 간(3세부터 6세까지) 조음 복잡성 정도에 따라 조음오류율, 조음산출의 변이성, 조음오류의 변이성, 반응시간의 변이성에 차이가 있는가? 둘째, 학령전기 말소 리장애 아동 집단과 일반 아동 집단 간 조음복잡성 정도에 따라 조 음오류율, 조음산출의 변이성, 조음오류의 변이성, 반응시간의 변 이성에 차이가 있는가? 모든 분석은 개별 말소리가 아닌, 단어 전체 를 대상으로 하였다. 예를 들어 목표단어 '토끼'를 [토기], [토이], [토 끼], [토끼]와 같이 발음하였다면, / ᄁᄁ/이 [ㄱ]로 대치되었는지 혹은 생략되었는지를 분석하는 것이 아니라 전체 단어/토끼/가 얼마나 다른 말소리 조합의 형태로 산출되었는지에 초점을 둔다. 이는 변이 성이 전체 단어를 형성하기 위해 연속된 말소리들을 선택하고 배열 하는 과정에서 일어나는 문제이기 때문이다. 조음오류율은 동일한 단어의 전체 산출횟수에 대한 오류단어의 비율을, 조음산출의 변 이성은 정조음과 오조음을 구분하지 않은 채 동일한 단어에 대한 조음산출의 변화를, 조음오류의 변이성은 오조음한 단어에서 오 조음 산출의 변화를, 반응시간의 변이성은 동일한 단어에 대해 그 림자극 제시부터 목표단어 산출시작까지 반응시간에 대한 4 회간 편차를 의미한다. 반응시간의 변이성에 대해 살펴본 연구는 성인 환자를 대상을 실시한 것밖에 찾을 수 없었다(Stuss, Murphy, Binns, \& Alexander, 2003). 그러나 아동기 말실행증과 같이 변이성이 높 은 아동 대상자의 경우에도 운동프로그래밍 결함으로 인해 발화 시작 시 반응시간이 상대적으로 길어질 가능성이 있으므로(Kim, Choi, \& Ha, 2015), 이에 대한 변이성을 살펴보는 것 또한 시사하는 바가 있을 것으로 판단하였다.

높은 변이성을 보이는 아동은 불명확한 음운표상, 불안정한 어 휘표상, 음운산출처리의 문제 등과 관련하여 어휘능력, 특히 표현 어휘능력의 결함, 더 나아가 전반적인 언어능력의 결함도 또한 보일 수 있다(Dodd, 2005). 즉, 말소리 산출의 변이성이 높은 대상자는 말소리장애뿐 아니라 언어장애도 동반할 가능성이 상대적으로 크 다. 따라서 변이성이 높은 말소리장애 아동의 특성을 파악하기 위 해서는 언어장애를 동반한 말소리장애 아동을 대상으로 연구를 진행하는 것이 보다 타당할 것이다. 그러나 본 연구에서는 동일한 단어의 반복적 산출을 유도하기 위한 방법으로 그림이름대기 과제 를 사용하였기 때문에, 언어장애 동반 아동의 경우 반응의 변이성 이 말소리 산출과정이 아닌 그림이름대기 과제 시 요구되는 기저의
인지-언어처리과정의 결함에 근거하였을 가능성을 배제할 수 없을 것으로 판단하였다. 이와 같은 이유로 본 연구에서는 결과해석의 타당성을 높이기 위해 언어장애를 동반하지 않은 순수 말소리장애 (pure SSD) 아동으로 대상자를 한정하였다. 따라서 본 연구는 높은 변이성을 보이는 말소리장애 집단의 산출 변이성에 대한 특성을 살 펴보았다기보다, 순수 말소리장애 아동의 산출 변이성이 일반 아동 의 발달과정에서 관찰되는 산출 변이성과 어떻게 다른지를 알아보 는 것을 그 목적으로 하였다는 것을 밝힌다.

\section{연구방법}

\section{연구대상}

본 연구는 3 세, 4 세, 5 세, 6 세의 일반 아동 각 15 명씩 총 60 명과 4-5세 말소리장애 아동 총 20 명을 대상으로 하였다. 일반 아동은 (1) 수용·표현어휘력검사(REVT: Kim, Hong, Kim, Jang, \& Lee, 2009)의 점수가 -1 SD 이상에 속하고, (2) 우리말 조음·음운평가 (U-TAP: Kim \& Shin, 2004)의 단어 수준에서 자음정확도가 -1 SD 이상에 속하고, (3) 부모 및 교사 보고를 통해 감각적, 신경학적, 신 체적, 인지적, 언어적 면에 아무런 문제가 없는 것으로 확인된 아동 으로 하였다. 말소리장애 아동은 (1) 수용·표현어휘력검사(REVT: Kim et al., 2009)의 점수가 -1 SD 이상에 속하고, (2) 우리말 조음. 음운평가(U-TAP: Kim \& Shin, 2004)의 단어 수준에서 자음정확 도가 - $2 \mathrm{SD}$ 이하에 속하고, (3) 조음기관의 구조적 장애가 관찰되지 않고, (4) 부모 및 교사보고를 통해감각적, 신경학적, 신체적, 인지적, 언어적 면에 아무런 문제가 없는 것으로 확인된 아동으로 하였다.

일반 아동의 경우 연령 집단 간 성별에 유의한 차이가 없었고 ( $p>$.05), 생활연령, REVT 수용 및 표현어휘 등가월령, 그리고 U-TAP 자음정확도에 유의한 차이가 있었다 $(p<.05)$. 말소리장애 아동 집 단과 생활연령을 일치시켜 통제 집단으로 선정된 일반 아동 25 명에 대해 기본적 특성을 비교한 결과, 두 집단 간 성별, 생활연령, REVT 수용 및 표현어휘 등가월령에는 유의한 차이가 없었고( $p>.05), \mathrm{U}$ $\mathrm{TAP}$ 자음정확도에만 유의한 차이를 보였다 $(p<.05)$. 각 연령 집단 별 일반 아동에 대한 대상자 정보는 Table 1에, 집단 간 비교를 위한 말소리장애 아동과 일반 아동에 대한 대상자 정보는 Table 2에 제 시하였다.

\section{연구도구}

\section{단어 선정}

Shin과 $\mathrm{Ha}$ (2015)의 연구에서 사용된 단어가운데 조음복잡성 과 단어등급을 고려하여 조음복잡성 '저(1-3)'와 '고(8-10)'의 수준 
Table 1. Participants' characteristics in TD groups

\begin{tabular}{|c|c|c|c|c|}
\hline \multirow{2}{*}{ Characteristic } & \multicolumn{4}{|c|}{ TD group } \\
\hline & 3 years $(N=15)$ & 4 years $(N=15)$ & 5 years $(N=15)$ & 6 years $(N=15)$ \\
\hline Gender (male:female) & $5: 10$ & $7: 8$ & $8: 7$ & $7: 8$ \\
\hline Chronological age (mo) & $42.93(3.57)$ & $54.00(3.10)$ & $66.53(3.38)$ & $76.40(1.96)$ \\
\hline \multicolumn{5}{|l|}{ REVT } \\
\hline Receptive vocabulary age (mo) & $44.73(13.80)$ & $62.60(12.67)$ & $74.13(10.75)$ & $99.53(14.10)$ \\
\hline Expressive vocabulary age (mo) & $46.40(13.15)$ & $61.40(11.97)$ & $76.73(12.60)$ & $94.93(12.98)$ \\
\hline \multicolumn{5}{|l|}{ U-TAP } \\
\hline PCC (\%) & $90.70(4.16)$ & 96.90 (3.02) & 98.60 (1.42) & 99.07 (1.14) \\
\hline
\end{tabular}

Values are presented as mean (SD).

TD = typically developing children; PCC= percentage of consonants correct; REVT= Receptive \& Expressive Vocabulary Test (Kim, Hong, Kim, Jang, \& Lee, 2009); U-TAP=Urimal Test of Articulation and Phonology (Kim \& Shin, 2004).
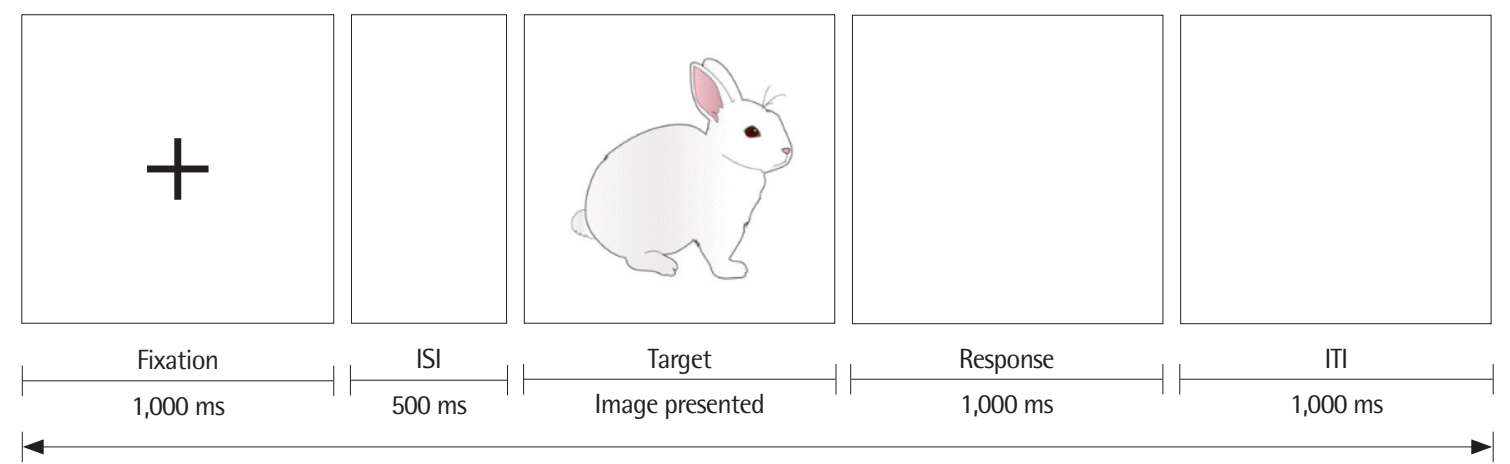

Randomly repeated 4 times

Figure 1. Design of $\mathrm{DmDx}$ program for articulatory variability task.

$|S|=$ inter stimuli interval; $|T|=$ inter trial interval.

Table 2. Participants' characteristics in SSD group and TD group

\begin{tabular}{lcc}
\hline Characteristic & SSD group (N=20) & TD group (N=25) \\
\hline Gender (male:female) & $12: 8$ & $13: 12$ \\
Chronological age (mo) & $53.75(4.41)$ & $58.20(5.84)$ \\
REVT & & \\
$\quad$ Receptive vocabulary age (mo) & $60.80(11.94)$ & $65.60(11.32)$ \\
$\quad$ Expressive vocabulary age (mo) & $59.20(11.60)$ & $62.32(11.13)$ \\
U-TAP & & \\
PCC (\%) & $85.23(4.05)$ & $97.49(2.62)$ \\
\hline
\end{tabular}

Values are presented as mean (SD).

$\mathrm{SSD}=$ speech sound disorder; $\mathrm{TD}$ = typically developing children; $\mathrm{PCC}=$ percentage of consonants correct; REVT= Receptive \& Expressive Vocabulary Test (Kim, Hong, Kim, Jang, \& Lee, 2009); U-TAP=Urimal Test of Articulation and Phonology (Kim \& Shin, 2004).

에서 각각 6 개씩을 선정하였다. 최종 실험 단어 목록은 Appendix 1 과 같다.

\section{실험과제 개발}

실험과제에 사용된 그림은 전문 일러스트레이터에게 의뢰하여
제작하였다. 1 차적으로 제작된 그림에 대해 정상 성인 5 명을 대상 으로 그림적절성 평가를 실시하였다. 그 결과 그림 6개에 대해 적절 성이 낮게 평가되어, 이 그림에 대해서는 http://www.google.co.kr 에서 사용제약이 없는 이미지를 참고하여 최대한 사실적으로 다시 제작해줄 것을 재의뢰하였다. 최종적으로 12 개의 그림이 완성되었 고, 그림 목록은 Appendix 2에 제시하였다.

실험과제 프로그램은 DmDx Software (Forster \& Forster, 2003) 를 사용하여 제작하였다. 노트북 모니터에 주의집중을 위한 + 표시 가 $1,000 \mathrm{~ms}$ 동안 제시되고 나서 $500 \mathrm{~ms}$ 의 inter stimuli interval (ISI) 후 실험자극 그림이 제시되었다. 대상자는 그림을 보자마자 바 로 해당 그림의 이름을 산출하였으며, 대상자의 반응은 자동으로 녹음되었고, inter trial interval (ITI)은 $1,000 \mathrm{~ms}$ 이었다. 변이성 측 정을 위해 12 개의 그림이 4 회씩 총 48 회 연속 제시되도록 하였다. 총 48 개의 그림은 Excel 랜덤함수에 의해 무작위 순서로 사전에 배 열되었다. 이때 우연적으로 동일한 그림이 연달아 나오는 경우를 방 지하기 위해 Excel 논리함수를 사용하였으나, 논리함수를 사용하 여도 연이어 동일한 그림이 나오는 경우는 연구자가 임의로 다른 순 
서로 배열하였다. 이와 같은 조음변이성 산출과제 프로그램의 구성 은 Figure 1과 같다.

\section{연구절차}

실험과제와 실험절차상 문제점을 파악하기 위해 일반 아동 2명 을 대상으로 예비 실험을 실시한 후 본 실험이 진행되었다. 소음이 없는 조용한 장소에서 사전평가를 실시한 후, 연구자는 아동과 마 주보고 앉아 실험에 사용된 목표단어를 대상 아동이 모두 알고 있 는지 사전에 확인하였다. 아동이 해당 그림에 대해 다른 이름으로 말한 경우, 목표단어를 여러 차례 반복 학습할 수 있는 시간을 충분 히 가졌다. 단어 확인 및 학습 시간 후 아동과 5 분 정도 대화 시간을 갖고 나서 본격적인 실험을 시작하였다. 실험 직전 아동은 마이크 가 내장되어 있는 헤드셋(DJH-500U)을 착용하였다. 실험 프로그 램이 저장된 13.3인치 노트북 컴퓨터(NT905S3G)를 제시한 후 연 구자는 아동에게 “그림을 보고 선생님에게 이게 무슨 그림인지 또 박또박 말해주세요.”라고 지시하였고, 아동이 그림을 보자마자 자 발적으로 목표단어를 산출하도록 유도하였다. 3 개의 연습문항을 통해 아동이 과제의 지시사항을 잘 이해하였는지 확인한 후, 무작 위로 제시된 12 개의 목표단어를 4 회씩 총 48 회 산출하도록 하였고, 아동의 반응은 헤드셋을 통해 모두 자동으로 녹음되었다.

\section{자료분석}

\section{조음오류율 측정}

조음오류율은 Betz와 Stoel-Gammon (2005)의 'proportion of errors' 계산방법을 참고하여, 동일한 단어에 대해 '조음오류를 보 인 단어의 수 / 전체 단어 산출의 수 $\times 100$ '으로 계산하였다. 예를 들면 /토끼/를 발음할 때 /토기/로 1번, /토니/로 1 번의 오류를 보이 고 2 번 정조음을 하였다면, 오류를 보인 산출의 수는 2 , 전체 단어 의 산출 수는 4 이다. 이 경우 조음오류율은 ' $2 / 4$ '가 된다. 만일 4 회 모두 목표단어를 정조음한다면 조음오류율은 $0 \%$ 이고, 모두 오조 음한다면 조음오류율은 $100 \%$ 가 된다. 이때 조음오류율이 $0 \%$ 인 경 우는 오류를 전혀 보이지 않았기 때문에 분석에서 제외하였다. 이 와 같은 방법으로 목표단어 모두에 대해 조음오류율을 각각 구한 후, 그 평균값을 대상자의 조음오류율 값으로 하였다. 따라서 본 연 구에서 조음오류율이란 단어 당 평균 오류율을 의미한다.

\section{조음산출의 변이성 측정}

조음산출의 변이성 측정은 Haley 등(2013)의 'total token variability' 계산방법을 참고하여, 동일한 단어에 대해 '서로 다른 산출 의 유형 수/전체 단어 산출의 수 $\times 100$ '으로 계산하였다. 이때 서로
다른 산출에는 정조음도 포함된다. 예를 들어 대상자가/토끼/를 발 음할 때, /토기/로 1 번, /토니/로 1 번 오류를 보이고, 2 번의 정조음을 하였다면, 이 때 대상자가 보인 서로 다른 산출의 가지 수는 /토기/, /토니/, /토끼/(정조음)로 3, 전체 산출 수는 4이다. 따라서 이 대상자 의 조음산출의 변이성은 ‘3/4’이 된다. 이와 같은 방법으로 산출한 단어 모두에 대해 조음산출의 변이성을 각각 구한 후 그 평균값을 각 대상자의 조음산출의 변이성 값으로 하였다.

\section{조음오류의 변이성 측정}

조음오류의 변이성 측정은 Haley 등(2013)의 'variability of error type' 계산방법을 참고하여, 동일한 단어에 대해 '서로 다른 조음오 류의 유형 수/전체 조음오류의 수 $\times 100$ '으로 계산하였다. 예를 들 면 대상자가 /토끼/를 발음할 때, /토기/로 1번, /토니/로 2번 오류를 보이고, 1 번의 정조음을 하였다면, 이 대상자가 보인 서로 다른 조 음오류 유형의 가지 수는 2, 전체 조음오류 수는 3이다. 이 때의 오 류의 변이성은 ' $2 / 3$ '가 된다. 이러한 방법으로 동일한 단어 모두에 대해 조음오류의 변이성을 각각 구한 후 그 평균값을 각 대상자의 조음오류의 변이성 값으로 하였다. 이때 4 회의 산출 동안 단 한 번 만 오류를 보인 경우 조음오류의 변이성이 나타나지 않은 것이므로, 이것은 분석에서 제외하였다.

\section{반응시간의 변이성 측정}

반응시간 측정을 위해 $\mathrm{DmDx}$ 와 연동되는 Check Vocal 프로그램 을 이용하였으나, Check Vocal에서 자동측정이 불분명한 경우 Praat 프로그램을 사용하여 재분석을 실시하였다. 화면에 목표그림이 제 시된 순간부터 아동이 단어를 산출하기 시작한 순간까지의 시간이 컴퓨터에 자동으로 기록되었다. Stuss 등(2003)의 'intra-individual coefficient of variation (ICV)' 계산방법을 참고하여, 동일한 단어에 대해 '반응시간의 표준편차/반응시간의 평균’으로 반응시간의 변이 성 값을 구하였다. 반응시간 연구의 보편적 실험방법을 따라 본 연구 에서도 반응시간 측정은 정반응한 항목에 한하여 실시하였다.

\section{신뢰도}

평가자 간 신뢰도를 위해 전체 대상자의 $20 \%$ 인 16 명의 자료를 무 작위로 추출하였다. 총 12 개의 단어를 4 회씩 반복한 전체 768 개의 단어에 대해 평가자 간 전사 신뢰도를 구하였다. 제 1 평가자는 본 연 구의 주저자였고, 제 2 평가자는 박사학위를 소지한 임상경력 10 년 이상의 1 급 언어재활사였다. 두 평가자가 아동의 발화를 독립적으 로 음성전사한 후 모든 자음에 대한 전사의 일치 정도를 계산하였 다. 전사가 일치한 자음의 수를 전사된 자음의 총 수인 2,304 로 나 
누어 100 을 곱한 결과, 평가자 간 신뢰도는 $97.44 \%$ 였다.

\section{통계분석}

자료의 통계처리는 SPSS ver. 20.0 (IBM, Armonk, NY, USA)을 이 용하여 분석하였다. 일반 아동의 연령 집단 간 조음복잡성 수준에 따른 조음오류율, 조음산출의 변이성, 조음오류의 변이성 및 반응시 간의 변이성에 유의한차이가 있는지 알아보기 위해 1 피험자간-1 피 험자 내 혼합설계에 의한 반복측정 분산분석(repeated measure ANOVA)을 실시하였다. 말소리장애 아동 집단과 일반 아동 집단 간 조음복잡성 수준에 따른 조음오류율, 조음산출의 변이성, 조음오류 의 변이성 및 반응시간의 변이성에 유의한 차이가 있는지 알아보기 위해, 마찬가지로 1 피험자간-1 피험자 내 혼합설계에 의한 반복측정 분산분석을 실시하였다. 구형성 가정이 충족되지 않을 경우 Greenhouse-Geisser의수정된 자유도를 이용하여 결과를 해석하였다.

\section{연구결과}

\section{일반 아동의 연령 집단 간 비교}

연령이 어릴수록 조음오류율, 조음산출의 변이성, 조음오류의 변 이성 및 반응시간의 변이성이 평균적으로 높게 나타났으며, 조음 복잡성 ‘저'보다 조음복잡성 ‘고'에서 조음오류율, 조음산출의 변이 성, 조음오류의 변이성 및 반응시간의 변이성이 평균적으로 높게 나타났다(Table 3).

일반 아동의 연령 집단 간 조음복잡성 수준에 따른 조음오류율 비교 일반 아동의 연령 집단 간 조음복잡성 수준에 따른 조음오류율 차이가 통계적으로 유의한지 알아본 결과, 집단 간 주 효과 $\left(F_{(3,56)}=\right.$
$27.317, p<.001)$, 조음복잡성 수준에 따른 집단 내 주 효과 $\left(F_{(1,56)}=\right.$ $103.633, p<.001)$, 조음복잡성 수준과 집단 간 상호작용효과 모두 유의하였다 $\left(F_{(3,56)}=8.43, p<.001\right)$. 집단 간 주 효과에 대해 Scheffe 사후검정을 실시한 결과 3 세와 4 세 $(p<.01), 5$ 세 및 6 세 집단 간 $(p<.001)$, 그리고 4 세와 6 세 집단 간 $(p<.01)$ 유의한 차이가 나타났 다. 조음복잡성 수준과 집단 간 상호작용효과를 구체적으로 알아 보기 위해 COMPARE 하위명령어 입력한 syntax를 실행시켜 사후 검정을 실시하였다. 그 결과 조음복잡성 '저' 수준에서는 3세와 4 세 $(p<.01), 5$ 세, 6세 집단 간 $(p<.001)$, 그리고 4 세와 6세 집단 간 $(p<.01)$ 유의한차이가 있었던 반면, 조음복잡성 '고' 수준에서는 3 세와 4 세, 5세, 6 세 집단 간 $(p<.001), 4$ 세와 5 세 $(p<.01), 6$ 세 집단 간 $(p<.001)$ 유의한 차이가 나타났다.

\section{일반 아동의 연령 집단 간 조음복잡성 수준에 따른 조음산출의} 변이성 비교

일반 아동의 연령 집단 간 조음복잡성 수준에 따른 조음산출의 변이성 차이가 통계적으로 유의한지 알아보기 위해 반복측정 분산 분석을 실시하였다. 그 결과 집단간주 효과 $\left(F_{(3,56)}=13.552, p<.001\right)$ 와 조음복잡성 수준에 따른 집단 내 주 효과가 유의하였다 $\left(F_{(1,56)}=\right.$ $33.271, p<.001)$. 그러나 조음복잡성 수준과 집단 간 상호작용효과 는 유의하지 않았다 $\left(F_{(3,56)}=2.518, p>.05\right)$. 집단 간 주 효과에 대해 Scheffe 사후검정을 실시한 결과, 3세와 5 세 $(p<.001), 3$ 세와 6세 $(p<.001), 4$ 세와 6세 $(p<.01)$ 집단간 유의한차이를 보였다.

\section{일반 아동의 연령 집단 간 조음복잡성 수준에 따른 조음오류의} 변이성 비교

일반 아동의 연령 집단 간 조음복잡성 수준에 따른 조음오류의

Table 3. Descriptive analysis on proportion of articulatory errors, variation of articulation, variation of articulatory error and variation of reaction time according to phonetic complexity level by age groups

\begin{tabular}{|c|c|c|c|c|c|}
\hline Phonetic complexity level & $\begin{array}{c}\text { Age group } \\
\text { (yr) }\end{array}$ & $\begin{array}{c}\text { Proportion of articulatory } \\
\text { errors }(\%)\end{array}$ & $\begin{array}{c}\text { Variation of articulation } \\
(\%)\end{array}$ & $\begin{array}{c}\text { Variation of articulatory } \\
\text { error }(\%)\end{array}$ & $\begin{array}{l}\text { Variation of reaction time } \\
\text { (ms) }\end{array}$ \\
\hline \multirow[t]{5}{*}{ Low } & 3 & $38.05(18.29)$ & $46.39(8.01)$ & $22.04(16.49)$ & $.309(.080)$ \\
\hline & 4 & $23.33(14.59)$ & $42.50(11.05)$ & $10.93(11.85)$ & $.291(.061)$ \\
\hline & 5 & $14.44(9.94)$ & $36.39(7.30)$ & $4.44(9.89)$ & $.265(.082)$ \\
\hline & 6 & $6.39(6.27)$ & $32.50(6.34)$ & $1.11(4.30)$ & $.228(.077)$ \\
\hline & Total & $20.56(17.41)$ & $39.44(9.78)$ & $9.63(13.80)$ & $.273(.079)$ \\
\hline \multirow[t]{5}{*}{ High } & 3 & $72.50(24.28)$ & $61.67(14.36)$ & $48.24(27.89)$ & $.333(.065)$ \\
\hline & 4 & $44.17(18.55)$ & $51.94(16.13)$ & $22.32(23.27)$ & $.324(.059)$ \\
\hline & 5 & $26.11(16.85)$ & $41.11(9.30)$ & $13.33(14.45)$ & $.330(.119)$ \\
\hline & 6 & $16.95(10.85)$ & $38.06(8.75)$ & $11.11(15.00)$ & $.228(.080)$ \\
\hline & Total & $39.05(27.82)$ & $48.19(15.43)$ & $23.75(25.24)$ & $.304(.093)$ \\
\hline
\end{tabular}

Values are presented as mean (SD). 
변이성 차이가 통계적으로 유의한지 알아본 결과, 집단 간 주 효과 $\left(F_{(3,56)}=12.532, p<.001\right)$, 조음복잡성 수준에 따른 집단 내 주 효과 $\left(F_{(1,56)}=37.124, p<.001\right)$, 그리고 조음복잡성 수준과 집단 간 상호 작용효과가 모두 유의하였다 $\left(F_{(3,56)}=3.069, p<.05\right)$. 집단의 주 효 과에 대해 Scheffe 사후검정을 실시한 결과, 3 세와 4 세 $(p<.05), 5$ 세 $(p<.001)$ 및 6세 집단 간 $(p<.001)$ 유의한 차이를 보였다. 조음복잡 성 수준과 집단 간 상호작용효과를 구체적으로 알아보기 위해, COMPARE 하위명령어 입력한 syntax를 실행시켜 사후검정을 실 시하였다. 그 결과 조음복잡성 '저' 수준에서 3세와 4 세( $p<.05), 5$ 세, 6 세 집단 간 $(p<.001)$, 그리고 4 세와 6 세 집단 간 $(p<.05)$ 유의한 차이를 보인 반면, 조음복잡성 '고' 수준에서는 3 세와 4 세 $(p<.01)$, 5 세, 6세 집단 $(p<.001)$ 에서만 유의한차이를 보였다.

\section{일반 아동의 연령 집단 간 조음복잡성 수준에 따른 반응시간의}

변이성 비교

연령 집단 간 조음복잡성 수준에 따른 반응시간의 변이성의 차 이가 통계적으로 유의한지 알아보기 위해 반복측정 분산분석을 실시하였다. 그 결과 집단 간 주 효과 $\left(F_{(3,56)}=5.99, p<.001\right)$, 조음복 잡성 수준에 따른 집단 내 주 효과가 유의하였으나 $\left(F_{(1,56)}=6.87\right.$, $p<.05)$, 조음복잡성 수준과 집단 간 상호작용효과는 유의하지 않 았다 $\left(F_{(3,56)}=1.34, p>.05\right)$. 집단 간 주 효과에 대해 Scheffe 사후검 정을 실시한 결과, 3 세와 6 세 $(p<.01), 4$ 세와 6 세 $(p<.05)$, 그리고 5 세와 6 세 $(p<.05)$ 집단 간 유의한차이를 보였다.

\section{말소리장애 아동과 일반 아동 집단 간 비교}

말소리장애 아동 집단보다 일반 아동 집단에서 조음오류율, 조 음산출의 변이성, 조음오류의 변이성 및 반응시간의 변이성이 평균 적으로 낮게 나타났고, 두 집단 모두 조음복잡성 '저' 수준보다 조음 복잡성 ‘고' 수준에서 조음오류율, 조음산출의 변이성, 조음오류의
변이성 및 반응시간의 변이성을 평균적으로 많이 보였다(Table 4).

말소리장애 아동과 일반 아동 집단 간 조음복잡성 수준에 따른 조음오류율 비교

말소리장애 아동과 일반 아동 집단 간 조음복잡성 수준에 따른 조음오류율의 차이가 통계적으로 유의한지 알아보기 위하여 반복 측정 분산분석을 실시하였다. 그 결과 집단 간 주 효과가 유의하였 고 $\left(F_{(1,43)}=37, p<.001\right)$, 조음복잡성 수준에 따른 집단 내 주 효과도 유의하였다 $\left(F_{(1,43)}=93.067, p<.001\right)$. 그러나 조음복잡성 수준과 집 단 간 상호작용효과는 유의하지 않았다 $\left(F_{(1,43)}=7.177, p>.05\right)$. 즉, 말소리장애 아동 집단이 일반 아동 집단보다 조음오류율이 유의하 게 높고, 집단에 상관없이 조음복잡성 '저'보다 '고'에서 조음오류 율이 유의하게 높았다.

말소리장애 아동과 일반 아동 집단 간 조음복잡성 수준에 따른 조음산출의 변이성 비교

말소리장애 아동과 일반 아동 집단 간 조음복잡성 수준에 따른 조음산출의 변이성 차이가 통계적으로 유의한지 알아보았다. 그 결 과 조음복잡성 수준에 따른 집단 내 주 효과만 유의하였고 $\left(F_{(1,43)}=\right.$ $22.033, p<.001)$, 집단 간 주 효과 $\left(F_{(1,43)}=2.608, p>\right.$.05) 및 조음복 잡성 수준과 집단 간 상호작용효과는 유의하지 않았다 $\left(F_{(1,43)}=.584\right.$, $p>.05)$. 집단에 상관없이 조음복잡성 '저'보다 '고'에서 조음산출의 변이성이 유의하게 높았으나, 말소리장애 아동과 일반 아동 간에는 조음산출의 변이성에 유의한 차이를 보이지 않았다.

\section{말소리장애 아동과 일반 아동 집단 간 조음복잡성 수준에 따른} 조음오류의 변이성 비교

말소리장애 아동과 일반 아동 집단 간 조음복잡성 수준에 따른 조음오류의 변이성 차이가 통계적으로 유의한지 알아본 결과, 집단

Table 4. Descriptive analysis on proportion of articulatory errors, variation of articulation, variation of articulatory error and variation of reaction time according to phonetic complexity level by groups

\begin{tabular}{lccccc}
\hline Phonetic complexity level & Group & $\begin{array}{c}\text { Proportion of articulatory } \\
\text { errors }(\%)\end{array}$ & $\begin{array}{c}\text { Variation of articulation } \\
(\%)\end{array}$ & $\begin{array}{c}\text { Variation of articulatory } \\
\text { error (\%) }\end{array}$ & $\begin{array}{c}\text { Variation of reaction time } \\
\text { (ms) }\end{array}$ \\
\hline Low & SSD & $44.17(23.58)$ & $43.96(9.88)$ & $20.28(13.77)$ & $.273(.059)$ \\
& TD & $20.33(13.25)$ & $40.67(10.01)$ & $8.56(11.76)$ & $.289(.064)$ \\
High & Total & $30.93(21.89)$ & $42.13(9.98)$ & $13.77(13.86)$ & $.282(.062)$ \\
& SSD & $75.42(17.88)$ & $54.38(11.10)$ & $38.54(16.77)$ & $.337(.089)$ \\
& TD & $38.00(19.89)$ & $48.17(14.64)$ & $19.50(20.96)$ & $.343(.090)$ \\
\hline
\end{tabular}

Values are presented as mean (SD).

$\mathrm{SSD}=$ speech sound disorder; $\mathrm{TD}=$ typically developing children. 
간 주 효과 $\left(F_{(1,43)}=14.330, p<.001\right)$ 및 조음복잡성 수준에 따른 집 단 내 주 효과가 유의하였다 $\left(F_{(1,43)}=28.997, p<.001\right)$. 그러나 조음 복잡성 수준과 집단 간 상호작용효과는 유의하지 않았다 $\left(F_{(1,43)}=\right.$ $1.821, p>.05)$.

\section{말소리장애 아동과 일반 아동 집단 간 조음복잡성 수준에 따른 반응시간의 변이성 비교}

말소리장애 아동과 일반 아동 집단 간 조음복잡성 수준에 따른 반응시간의 변이성에 통계적으로 유의한 차이가 있는지 알아보기 위해 반복측정 분산분석을 실시하였다. 그 결과 집단 간 주 효과가 유의하지 않았으나 $\left(F_{(1,43)}=.51, p>.05\right)$, 조음복잡성 수준에 따른 집 단 내 주 효과는 유의하였다 $\left(F_{(1,43)}=12.782, p<.001\right)$. 조음복잡성 수준과 집단 간상호작용효과도 유의한 차이를 보이지 않았다 $\left(F_{(1,43)}\right.$ $=.10, p>.05)$.

\section{논의 및 결론}

본 연구에서는 일반 아동과 말소리장애 아동의 조음복잡성 수 준에 따른 조음오류율, 조음산출의 변이성, 조음오류의 변이성, 반 응시간의 변이성을 비교하고 그 특성을 파악하고자 하였다. 연구결 과 일반 아동은 연령이 높아짐에 따라 조음오류율, 그리고 조음산 출, 조음오류, 반응시간의 변이성이 낮아졌고, 말소리장애 아동은 동일 연령대의 일반 아동보다 조음오류율과 조음오류의 변이성이 유의하게 높았다. 이와 같은 연구결과를 각 분석지표별로 정리해보 면 다음과같다.

첫째, 조음오류율의 경우 일반 아동 3세 집단은 조음복잡성 '저' 와 ‘고' 모두에서 나머지 연령대 집단들보다 유의하게 높았다. 4 세 집단은 조음복잡성 '저'에서는 6세와만 유의한 차이를 보인 반면, 조음복잡성 '고'에서는 5 세와도 유의한 차이를 보였다. 즉, 조음복 잡성이 높은 경우 연령에 따른 조음오류율의 차이가 보다 민감하게 드러난다는 것을 알 수 있다. 조음복잡성 '고'에서 4 세 아동의 조음 오류율이 평균 $44.17 \%$ 라는 결과(Table 3)는 동일한 단어를 여러 차 례 산출하게 하였을 때 대략 절반은 정조음을, 나머지 절반은 오조 음을 보였다는 것을 의미한다. 이는 단 한 차례의 기회만을 제공하 고 그것을 아동의 대표적인 말소리 산출 능력으로 간주하는 평가 방법의 방법적인 제한점을 시사한다. 즉, 한 차례의 산출기회만을 제공할 경우 우연적으로 해당 말소리를 정조음 또는 오조음하는 것으로 평가할 가능성을 배제할 수 없을 것이다.

한편 말소리장애 집단의 경우, 조음복잡성 정도에 상관없이 일 반 집단보다 조음오류율이 유의하게 높았다는 결과는 오류 자체를
많이 보이는 대상 집단의 특성상 당연한 결과로 여겨진다. 그러나 조음복잡성 '고'에서 말소리장애 집단의 조음오류율이 $75.42 \%$ 라 는 결과(Table 4)로, 말소리장애가 있다고 하여 조음적으로 복잡한 단어에 대한 오류율이 $100 \%$ 에 가까운 것은 아니라는 것을 알 수 있다. 다시 말해 조음복잡성이 높은 경우에도 말소리장애 아동이 오류를 보이는 말소리를 항상 오조음하는 것은 아니라는 것이다. 따라서 말소리장애 아동의 조음평가 시 일관되게 오조음을 보이는 말소리와 정조음을 할 수 있는 오조음을 구분하여 살펴보는 것이 필요할 것이다.

둘째, 조음산출의 변이성과 조음오류의 변이성의 차이는 분석 시 정조음을 분석항목에 포함하였는지 여부에 따른 것이다. 전자 는 정조음을 포함하여 분석한 것이고, 후자는 정조음을 제외한 후 오조음 내에서만 변이성을 분석한 것이다. 일반 아동의 경우 대략 적으로 조음산출과 조음오류 모두에서 3 세와 4 세가 5 세와 6 세보 다 변이성이 유의하게 높았다. 좀 더 자세히 살펴보면 조음산출의 변이성은 조음복잡성 '저'에서는 3세 평균 $46.39 \%, 4$ 세 평균 $42.50 \%$ 이었고, 조음복잡성 '고'에서는 3 세 평균 $61.67 \%, 4$ 세 평균 $51.94 \%$ 였다(Table 3). 즉 총 4 회의 산출 기회에서 산출의 가짓수가 조음복 잡성 '저'에서는 두 가지 이하이고, '고'에서는 두 가지 이상이라 할 수 있다. 이는 조음복잡성이 낮을 경우 정조음과 한 가지 형태의 오 조음을, 조음복잡성이 높을 경우 정조음과 두 가지 이상의 오조음 형태를 보일 가능성을 제시한다. 이러한 가능성을 확인하기 위해 조음오류의 변이성을 살펴본 결과, 3 세의 경우 조음복잡성 '고'에 서 조음오류의 변이율이 $50 \%$ 에 가까워(48.24\%) 오류 형태의 가지 수가 비교적 다양하다는 것을 알 수 있다. 조음오류의 변이성에서 는 연령 집단과 조음복잡성 정도 간 상호작용효과 또한 유의하였 는데, 조음복잡성 '저'에서는 4세와 6세 간 차이가 유의하였던 것에 반해 '고'에서는 그 차이가 유의하지 않았다. 이는 조음복잡성이 높 을 경우 6세도 어느 정도는 여전히 오류의 변이성을 보이기 때문에 4 세와의 집단 간 차이가 나타나지 않은 것으로 판단된다(Table 3).

반면 말소리장애 아동의 경우 조음산출의 변이성은 일반 아동 과 유의한 차이가 없었으나, 조음오류의 변이성은 일반 아동보다 유의하게 높았다. 조음산출의 변이성이 정조음과 오조음의 구분 없이 가짓수를 헤아린 것이라는 점을 상기할 때, 일반 아동의 경우 정조음과 오조음을 번갈아 산출하였을 가능성, 이에 반해 말소리 장애 아동은 여러 차례의 오조음을 산출하고 그 오조음의 형태가 다양하였을 가능성을 생각해볼 수 있다. 조음오류의 변이성이 말 소리장애 아동에서 유의하게 높았다는 결과, 그리고 목표단어 목 록에 말소리장애 아동이 오류를 많이 보이는 유음, 치경마찰음, 경 구개파찰음이 다수 포함되었다는 점은 이러한 가능성을 더욱 지지 
한다. 그러나 보다 정확한 결론을 도출하기 위해서는 대상자의 반 응을 질적으로 분석하여 비교하는 추후 연구가 필요할 것이다.

셋째, 반응시간의 변이성을 비교한 결과 일반 아동의 6세 집단은 3 세, 4 세, 5 세 집단보다 유의하게 변이성이 낮았다. 그러나 말소리장 애 집단과 일반 아동 간 차이는 유의하지 않았다. 즉 6세가 되면 그 보다 어린 연령의 아동들보다 반응시간의 편차가 줄어들어 시간적 으로 안정된 반응을 하게 되며, 말소리장애 아동이라고 하여 동일 연령대의 일반 아동보다 시간적으로 더 가변적인 양상을 보이는 것 은 아니다. 그러나 상기할 점은 본 연구에서 반응시간 분석은 정반 응한 항목에 한하여 실시했다는 것과 말소리장애 집단은 말소리 산출 능력 이외에 다른 능력은 정상 범주에 속하는 순수 말소리장 애 아동들이었다는 것이다. 오반응한 항목에 대해서도 이와 같이 일관되고 안정된 반응시간을 보이는지, 그리고 순수 말소리장애 아동이 아닌 다른 장애를 동반한 말소리장애 또는 말실행증적 특 징을 동반한 말소리장애 아동의 경우 이와 다른 양상을 보이지는 않는지에 대해 추후 보다 심층적인 연구가 필요할 것이다.

이상과 같이 살펴보았듯이, 본 연구결과 3-4세의 일반 아동은 그 보다 연령이 높은 아동보다 조음오류, 조음산출, 조음오류 및 반응 시간에서 유의하게 높은 변이성을 보였다. 이것은 4 세에서는 조음 산출 및 조음오류의 변이성이 나타나지 않았다는 Hwang과 $\mathrm{Ha}$ (2012)의 연구와는 다른 결과이다. Hwang과 $\mathrm{Ha}$ (2012)의 연구와 달리 본 연구에서는 조음복잡성이라는 요인을 고려하여 목표단어 를 선정하였기 때문에, 이와 같이 다소 상이한 결과가 초래된 것으 로 판단된다. 본 연구에서 집단에 상관없이 항상 일관된 영향을 미 친 변수는 조음복잡성이었다. 연령에 상관없이, 그리고 장애유무 에 상관없이, 조음복잡성 ‘고' 단어는 조음복잡성 ‘저’ 단어보다 모 든 지표에서 유의하게 변이성이 높았다. 조음복잡성은 자음의 조 음위치와조음방법, 모음의 종류, 음절 형태, 어절 길이, 인접자음의 출현여부와 조음위치에 따라 난이도를 구분한 것으로, 음운 차원 이 아닌 조음 차원의 복잡성이다. 조음적으로 복잡할수록 변이성 이 높아진다는 본 연구결과는 변이성이 음운 단계뿐 아니라 조음 실행의 어려움으로 인해서도 초래될 수 있음을 제시한다. 실제로 조음변이성에 대한 선행연구들을 살펴보면, 조음변이성에는 미숙 한 말-운동 제어시스템(Kent, 1992), 음운시스템의 불안정(Ferguson \& Farwell, 1975; Leonard, Rowan, Morris, \& Fey, 1982), 음운 계획장애(Dodd et al., 2005), 음운표상의 결함(Macrea, 2013; Sosa \& Stoel-Gammon, 2006), 제한된 음운지식(Sosa \& Stoel-Gammon, 2012), 연령(Macrea, 2013), 표현어휘 능력(Sosa \& Stoel-Gammon, 2012) 등과 같이 다양한 요인들이 영향을 미치는 것으로 보고되었 다. 이와 같은 점을 고려할 때 Dodd 등(2005)이 제안한 네 번째 말
소리장애 하위집단을 비일관적 ‘음운장애’라고 하는 것보다 비일 관적 '말소리장애'로 좀 더 포괄적으로 명명하는 것이 보다 타당할 지도 모르겠다. 더불어 연령이 어린 일반 아동의 경우에도 빈번하 게 변이성을 보인다는 연구결과를 고려할 때, 성숙과정 중 나타나는 가변성(variability)과 병리적 혹은 비정상적 비일관성(inconsistency)의 두 가지 차원으로 변이성을 구분하여 접근할 필요성이 있다.

아동들은 4 세 이후 대부분의 말소리를 습득하여 안정적으로 산 출할 수 있게 된다. 이 시기와 맞물려 말소리를 일관적으로 산출할 수도 있게 되고 변이성도 줄어든다는 것을 본 연구를 통해 확인하 였다. 그러나 말소리장애 집단은 말소리습득 면에서도 발달이 늦을 뿐 아니라 일관적인 말소리 산출 능력도 더디게 발달하여, 4 세에서 도 동일 연령대의 일반 아동보다 변이성이 높다는 것 또한 본 연구 결과 알 수 있었다. 특히 오류를 보이는 말소리 내에서 오조음의 가 변성을 측정하는 조음오류의 변이성은 말소리장애 아동을 변별적 으로 진단할 수 있는 좋은 지표임을 제시하였다. 본 연구의 대상자 들은 모두 순수 말소리장애 아동들이었기 때문에, 결함 정도는 비 교적 경미하였고 특정 일부 음소만을 오조음하는 조음장애 집단 에 속하는 아동들이 대부분이었다. 그럼에도 불구하고 일반 아동 집단보다 유의하게 높은 조음오류의 변이성을 보였다는 본 연구결 과는 변이성이 비일관적 음운장애 또는 말실행증 집단만의 특성이 아닐 수 있음을 시사한다. 말소리장애 하위집단 간 조음오류뿐 아 니라 조음변이성의 특성을 비교하는 것은 각 집단의 변별적 특성 을 보다 심층적으로 파악하는 데에 분명 도움이 될 것이다. 문맥 변 화 없이 동일한 단어를 여러 차례 산출을 하게 한 후, 이에 대한 말소 리 산출 반응을 비교하는 평가방법은 변이성을 보이는 대상자들의 서로 다른 특성에 접근하는 데에 의미 있는 정보를 제공할 것이다.

\section{REFERENCES}

Betz, S. K., \& Stoel-Gammon, C. (2005). Measuring articulatory error consistency in children with developmental apraxia of speech. Clinical Linguistics and Phonetics, 19, 53-66

Dodd, B. (2005). Differential diagnosis and treatment of children with speech disorder. London: Whurr.

Dodd, B., Holm, A., Crosbie, S., \& McCormack, P. (2005). Differential diagnosis of phonological disorders. In B. Dodd (Ed.), Differential diagnosis and treatment of children with speech disorder (pp. 44-70). London: Whurr.

Ferguson, C. A., \& Farwell, C. B. (1975). Words and sounds in early language acquisition. Language, 51, 419-439.

Forster, K. L., \& Forster, J. C. (2003). DMDX: a windows display program 
with millisecond accuracy. Behavior Research Methods, Instruments, \& Computers, 35, 116-124.

Haley, K. L., Jacks, A., \& Cunningham, K. T. (2013). Error variability and the differentiation between apraxia of speech and aphasia with phonemic paraphasia. Journal of Speech, Language, and Hearing Research, 56, 891-905.

Holm, A., Crosbie, S., \& Dodd, B. (2007). Differentiating normal variability from inconsistency in children's speech: normative data. International Journal of Language and Communication Disorders, 42, 467-486.

Hwang, J. K., \& Ha, S. H. (2012). A study of articulatory variation in typically developing children between 2 and 4 years of age. Communication Sciences \& Disorders, 17, 403-413.

Ingram, D. (2002). The measurement of whole-word production. Journal of Child Language, 29, 713-733.

Kent, R. D. (1992). The biology of phonological development. In C. A. Ferguson et al. (Eds.), Phonological development: models, research, implications. Timonium, MD: York Press.

Kim, H. J., Choi, S. Y., \& Ha, J. W. (2015). Speech-motor program/programming in children with childhood Apraxia of speech, children with articulatory and phonological disorders and typically developing children. Communication Sciences \& Disorders, 20, 60-71.

Kim, M. J., Kim, S. J., Ha, J. W., \& Ha, S. H. (2015). A survey of co-morbidity and speech-language characteristics in speech sound disorders. Communication Sciences \& Disorders, 20, 446-455.

Kim, S. J., \& Shin, J. Y. (2015). Speech sound disorders. Seoul: Sigma Press.

Kim, Y. T., \& Shin, M. J. (2004). Urimal test of articulation and phonology (UTAP). Seoul: Hakjisa.
Kim, Y. T., Hong, G. H., Kim, K. H., Jang, H. S., \& Lee, J. Y. (2009). Receptive \& expressive vocabulary test (REVT). Seoul: Seoul Community Rehabilitation Center.

Leonard, L. B., Rowan, L. E., Morris, B., \& Fey, M. E. (1982). Intra-word phonological variability in young children. Journal of Child Language, 9, 55-69.

Macrea, T. (2013). Lexical and child-related factors in word variability and accuracy in infants. Clinical Linguistics \& Phonetics, 27, 497-507.

Macrea, T., Tyler, A., \& Lewis, K. (2014). Lexical and phonological variability in preschool children with speech sound disorder. American Journal of Speech-Language Pathology, 23, 27-35.

McLeod, S., \& Hewett, S. R. (2008). Variability in the production of words containig consonant clusters by typical 2-and 3-year-old children. Folia Phoniatrica et Logopaedica, 60, 163-172.

Shin, G. E., \& Ha, J. W. (2015). The effects of phonetic complexity on the disfluency and articulation errors of children with speech sound disorders. Journal of Speech-Language \& Hearing Disorders, 24(1), 91-102.

Sosa, A, V., \& Stoel-Gammon, C. (2012). Lexical and phonological effects in early word production. Journal of Speech, Language, and Hearing Research, 55, 596-608.

Sosa, A. V., \& Stoel-Gammon, C. (2006). Patterns of intra-word phonological variability during the second year of life. Journal of Child Language, 33, 3150.

Stuss, D. T., Murphy, K. J., Binns, M. A., \& Alexander, M. P. (2003). Staying on the job: the frontal lobes control individual performance variability. Brain, 126, 2363-2380. 
Eun-Ji Han, et al. • Articulatory Variability in SSD and TD

Appendix 1. Target word list according to phonetic complexity levels (low/high)

\begin{tabular}{|c|c|c|c|c|c|c|c|}
\hline \multirow{2}{*}{ No } & \multicolumn{3}{|c|}{ Phonetic complexity (low) } & \multirow{2}{*}{ No } & \multicolumn{3}{|c|}{ Phonetic complexity (high) } \\
\hline & Target word & Phonetic complexity score & Word grade & & Target word & Phonetic complexity score & Word grade \\
\hline 1 & 토끼 & 1 & 1 & 7 & 소방차 & 8 & 3 \\
\hline 2 & 새 & & 1 & 8 & 책상 & 9 & 1 \\
\hline 3 & 하마 & & 2 & 9 & 자전거 & & 1 \\
\hline 4 & 시소 & 2 & 3 & 10 & 잠자리 & & 2 \\
\hline 5 & 모자 & & 1 & 11 & 색종이 & 10 & 2 \\
\hline 6 & 구름 & 3 & 1 & 12 & 주전자 & & 1 \\
\hline
\end{tabular}

Appendix 2. Pictures in the experimental task

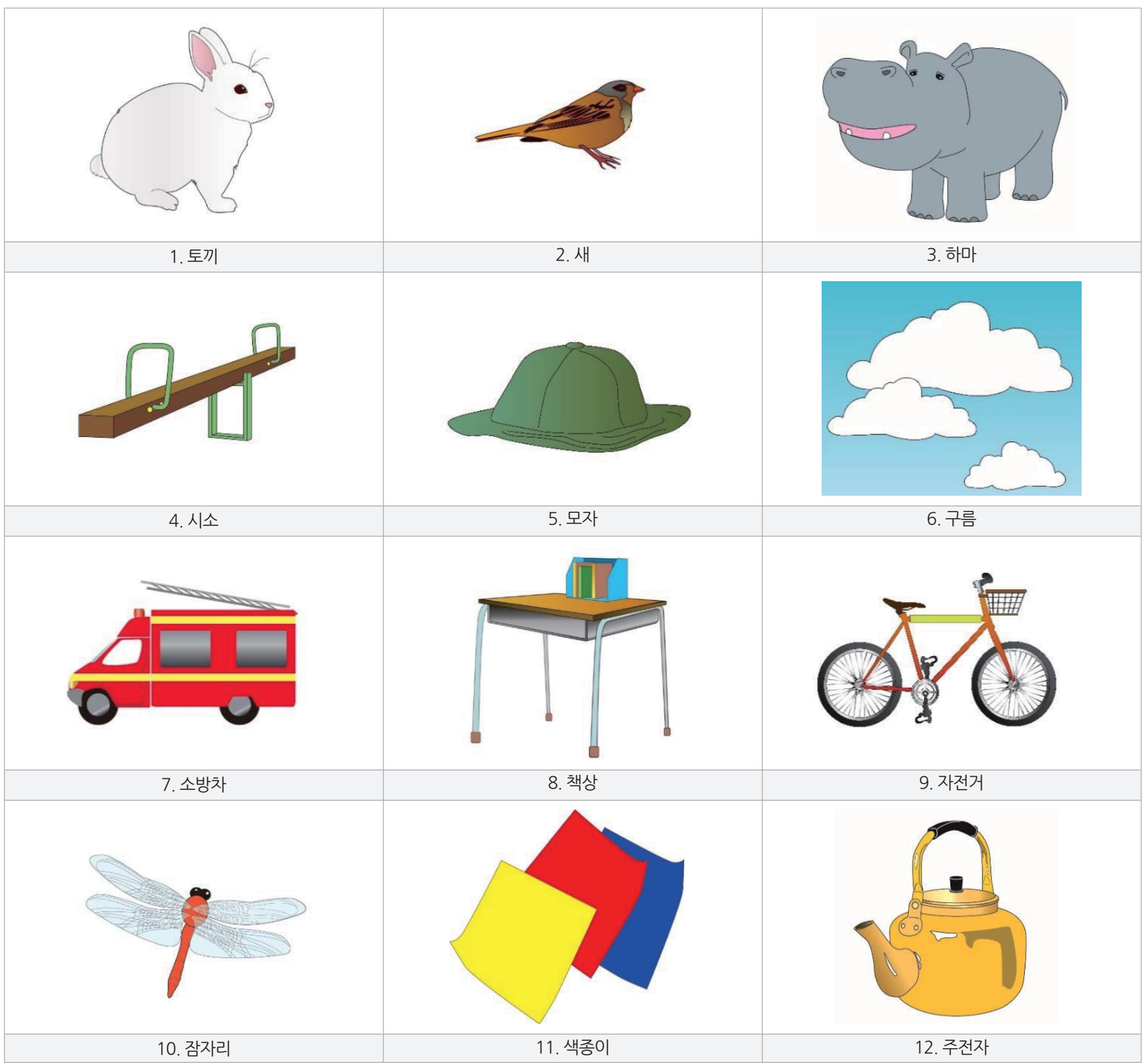




\section{국문초록}

\section{말소리장애 아동과 일반 아동의 조음복잡성에 따른 조음변이성 연구}

한은지 ${ }^{1}$ 하지완 ${ }^{2}$

'대구대학교 일반대학원 재활과학과 언어치료전공, ${ }^{2}$ 대구대학교 언어치료학과

배경 및 목적: 본 연구에서는 말소리장애 아동과 일반 아동을 대상으로 조음복잡성 정도에 따른 조음오류율, 조음산출의 변이성, 조음 오류의 변이성 및 반응시간의 변이성에 대한 차이를 살펴보고, 그 특성을 비교하고자 하였다. 방법: 연구대상자는 3 세부터 6 세까지의 일반 아동 60명과 4-5세 순수 말소리장애 아동 20명이었다. 조음복잡성 '고'와 조음복잡성 '저'에 해당하는 목표단어에 대해 각각 4 회씩 산출을 유도하는 실험과제를 DmDX Display Software로 제작하였다. 조음오류율, 조음산출의 변이성, 조음오류의 변이성 및 반응시간 의 변이성에 대한 지표를 구한 후, 각 연령 집단별, 그리고 말소리장애 아동과 일반 아동 간 집단 비교를 실시하였다. 결과: 일반 아동의 경우 연령이 증가함에 따라 조음오류율, 조음산출의 변이성, 조음오류의 변이성 및 반응시간의 변이성은 낮아졌으며, 조음복잡성 '저' 보다 ‘고’에서 모든 변이성 지표가 유의하게 높았다. 말소리장애 아동은 일반 아동보다 유의하게 높은 조음오류율과 조음오류의 변이성 을 보였으나, 조음산출의 변이성과 반응시간의 변이성에는 두 집단 간 차이가 유의하지 않았다. 말소리장애 집단에서도 조음복잡성 정 도는 모든 변이성 지표에 유의한 영향을 주었다. 논의 및 결론: 본 연구결과는 변이성이 비일관적 음운장애 집단만의 특성이 아니라, 정 상적 성숙과정과 다양한 말소리장애 집단에서도 나타날 수 있는 증상임을 시사한다.

핵심어: 말소리장애, 조음복잡성, 조음오류율, 조음산출의 변이성, 조음오류의 변이성, 반응시간의 변이성

본 연구는 2013년 정부(교육부)의 재원으로 한국연구재단의 지원을 받아 수행된 연구임(No. NRF-2017R1C1B1010913).

이 논문은 제1저자의 석사학위 논문 내용을 바탕으로 작성되었음.

\section{참고문헌}

김민정, 김수진, 하지완, 하승희(2015). 말소리장애의 동반장애 유형 및 말-언어 특성에 관한 설문조사. 언어청각장애연구, 20, 446-455.

김수진, 신지영(2015). 말소리장애. 서울: 시그마프레스.

김영태, 신문자(2004). 우리말 조음·음운평가(U-TAP). 서울: 학지사.

김영태, 홍경훈, 김경희, 장혜성, 이주연(2009). 수용·표현어휘력검사(REVT). 서울: 서울장애인종합복지관.

김효정, 최선영, 하지완(2015). 아동기 말실행증, 조음음운장애 및 일반 아동의 말-운동프로그램/프로그래밍 능력 비교. 언어청각장애연구, 20, 60-

71.

신가은, 하지완(2015). 말소리장애 아동의 조음복잡성에 따른 비유창성 및 조음오류 특성. 언어치료연구, 24, 91-102.

황진경, 하승희(2012). 2세 후반-4세 아동의 조음 변이성 연구. 언어청각장애연구, 17, 403-413. 